\title{
Metagenomic analysis of the microbial community in Çal Cave soil to elucidate biotechnological potential
}

\author{
Hasan Demirci $^{\text {a }}$ (D), Emel Ordu ${ }^{\text {a,* }}$ (iD
}

\begin{abstract}
Turkey has a great number of karstic caves which are unexplored and have unknown microbial diversity. The biodiversity characterisation of these caves has not yet been systematically studied from the molecular point of view. Çal Cave in Trabzon, Turkey is one of the important karstic caves. In the present study, a metagenomic approach was used to explore the microbial diversity of Çal Cave for the first time to assess the potential of gene sources. Detailed taxonomic profiling was defined by sequencing all environmental genomes instead of a specific marker gene such as 16S rRNA which only targets prokaryotes. Taxonomic analysis revealed that the Çal Cave soil sample was represented as 98\% Bacteria, 2\% Eukaryota, $0.3 \%$ Archaea, and $0.01 \%$ Virus. Results showed that, the 31 distinct bacterial phyla represented in the Çal Cave soil sample were dominated by Actinobacteria (65\%) and Proteobacteria (31\%). The most dominant bacterial genus was Streptomyces. Among the 2\% Eukaryotic population, the largest phylum was Ascomycota and it was mostly represented as Sordariomycetes. It was determined that $77 \%$ of Archaea was Halobacteria. The most abundant class of viruses dwelling in Cal Cave was Caudovirales. $91.61 \%$ of total readings could not be classified into any specific kingdom. Overall, classified and unclassified data verify that there exists vast microbial biodiversity in Çal Cave which could not be identified with classical microbiology techniques, and this microbial diversity provides a promising gene source for novel enzyme and bioactive compounds to be used in biotechnological applications.

Keywords: Actinobacteria, Cave soil, Metagenomics, Proteobacteria, Taxonomic profiling
\end{abstract}

\section{Çal Mağarası toprak mikrobiyal çeşitliliğindeki biyoteknolojik potansiyelin metagenomik analizi}

\begin{abstract}
Özet: Türkiye henüz araştırılmamış ve mikrobiyal çeşitliliği belirlenmemiş çok sayıda karstik mağaraya sahiptir. Bu mağaraların biyoçeşitlilik karakterizasyonu henüz moleküler bakış açısıyla ele alınarak sistematik bir şekilde incelenmemiştir. Trabzon'da yer alan Çal Mağarası önemli karstik mağaralardan biridir. Bu çalışmada Çal Mağarası'nın gen kaynaklarının biyoteknolojik potansiyelini değerlendirmek amacıyla, mağaranın mikrobiyal çeşitliliği ilk kez metagenomik yaklaşım ile araştırılmıştır. Detaylı taksonomik sınıflandırma 16S rRNA gibi sadece prokaryotları hedef alan spesifik bir markör gen yerine tüm çevresel genomların dizilenmesi ile gerçekleştirilmiş̧ir. Taksonomik analize göre Çal Mağarası toprağındaki mikrobiyal çeşitliliğin \%98'ni bakteriler, $\% 2$ 'sini ökaryotlar, \%0.3'ünü arkealar ve \%0.01'ini virüsler temsil etmektedir. Sonuçlar, Çal Mağarası toprak örneğinde temsil edilen 31 farklı bakteri filumunun \%65'inin Actinobacteria ve \%31'inin Proteobacteria olduğunu göstermektedir. Bunlar arasında en baskın bakteri cinsi Streptomyces olarak tespit edilmiştir. \%2'lik ökaryotik popülasyon arasında en geniş filum Ascomycota'dır ve bu filumun toprak örneği içindeki en yaygın temsilcisinin Sordariomycetes olduğu görülmüştür. Arkeaların \%77'sinin Halobacteria olduğu belirlenmiştir. Çal Mağarası toprağında yaşayan en yaygın virüs sınıfının Caudovirales olduğu ortaya çıkmıştır. Toplam okumaların \%91.61'i için ise herhangi bir spesifik sınıflandırma yapılamamıștır. Sınıflandırılmış ve sınıflandırılmamış tüm verilere bakıldığında Çal Mağarası'nda klasik mikrobiyoloji teknikleriyle tanımlanamayacak olan çok büyük bir mikrobiyal biyoçeşitliliğin olduğunu ve bu mikrobiyal çeşitliliğin biyoteknolojik uygulamalarda kullanılacak yeni enzim ve biyoaktif bileşenlerin keşfi için umut verici bir gen kaynağı sağladığ doğrulanmaktadır.

Anahtar kelimeler: Aktinobakteriler, Mağara Toprağı, Metagenomik, Proteobakteriler, Taksonomik sınıflandırma
\end{abstract}

\section{Introduction}

Investigation of novel species of microorganisms is an important strategy for the discovery of new bioactive compounds which have antibiotic, antimetabolite or antitumor activity, and have genes that code industrially important proteins (Ghosh et al., 2017). Caves, which are extreme environments in terms of microbial diversity, are ideal habitats for searching for novel microorganisms and, consequently, new compounds and proteins. Caves represent unique ecosystems with extreme conditions such as darkness, nutrient limitation, low oxygen level, high humidity, low temperature and high-level concentrations of minerals (Grothet et al., 1999; Schabereiter-Gurtner et al., 2003; Zhou et al., 2007). Because of these harsh conditions, caves contain rich and largely undiscovered microbial diversity and cave-dwelling microorganisms have unique properties from which to explore novel enzymes and different bioactive substances (Oliveira et al., 2017; Riquelme et al., 2017; Wiseschart et al., 2018). However,

\footnotetext{
$\bowtie$ a Department of Molecular Biology and Genetic, Faculty of Arts \& Sciences, Yıldız Technical University, Istanbul, Turkey

@* Corresponding author (İletişim yazarı): bemel@ yildiz.edu.tr

$\checkmark \quad$ Received (Geliş tarihi): 12.12.2019, Accepted (Kabul tarihi): 29.05.2020
}

Citation (Atıf): Demirci, H., Ordu, E., 2020. Metagenomic analysis of the microbial community in Çal Cave soil to elucidate biotechnological potential. Turkish Journal of Forestry, 21(3): 254-259. DOI: $10.18182 /$ tjf.658468 
caves have not yet received the attention they deserve, and studies on cave microbial diversity are typically based on traditional cultivation methods which can identify only an estimated $1 \%$ of cave microbial flora (Cheeptham, 2012).

Most cave microorganisms cannot be cultured and isolated because their original living conditions cannot be provided in the laboratory (Ghosh et al., 2017). Recent studies have shown that owing to the next-generation of sequencing technology, metagenomics which is a cultureindependent approach, provides a wealth of information on the whole microbial diversity of cave habitats as well as on novel genes and their functional properties (Rastogi and Sani, 2011; Mendoza et al., 2016; Jones et al., 2016; Katz et al., 2016). Literature shows that metagenomic mining of novel genes from cave habitats is still in its infancy and most of the studies reported so far have generally implemented sequencing of the 16S rRNA gene clone library for profiling the microbial diversity. Genes encoding the 16S rRNA subunit contain 9 regions (V1-V9) which have hypervariable and evolutionary conserved amino acid sequences. Each of these regions or complete $16 \mathrm{~S}$ rRNA sequence has been recently used for discriminating and analysing the bacterial diversity of several caves. D'Auria et al. (2018) reported seven phyla - Proteobacteria, Firmicutes, Chloroflexi, Chlorobi, Bacteroidetes, Actinobacteria and Acidobacteria dwelling in Villa Luz caves, in the southern Mexican state of Tabasco by reading the bacterial $16 \mathrm{~S}$ rRNA gene sequences spanning V1-V3 hypervariable regions. Wiseschart et al. (2018) investigated the bacterial diversity and potential of secondary metabolites of ManaoPee Cave in Thailand by comparing 16S rRNA sequences. They showed that Actinobacteria highly dominated ManaoPee Cave soil and it has a promising wealth of microbialderived bioactive compounds. In a different study, De Mandal et al. (2017) identified the bacterial community dominated by Actinobacteria and Proteobacteria in five unnamed caves in Northeast India by analysing the V3 hypervariable region of the 16S rRNA gene amplicon.

Turkey has a great number of karstic caves compared to European countries. The biodiversity characterisation of the microorganisms dwelling in these caves could represent an opportunity to develop biotechnological applications, as most have not yet been systematically studied from the molecular point of view. Çal Cave in Trabzon, Turkey is one of the most important karstic caves. Until now, the microbial investigation of Çal Cave has not been reported either by using culture-dependent or independent approaches. Therefore, in this study, we conducted a metagenomic analysis to explore the microbial diversity of Çal Cave for the first time to assess the potential of gene sources in terms of new enzymes and bioactive compounds.

In contrast to the previous cave studies mentioned above, the present study represents not only a detailed taxonomic profiling of bacteria and archaea, but also of fungi, algae, virus and protozoa owing to an independent sequencing approach from amplification of the taxonomic gene marker, 16S rRNA, which only targets prokaryotes. Also, complete next-generation sequencing of the metagenome extracted from our microbial community provides data for analysis of the relative abundance of microbial species and more reliable quantification of the microorganisms through assessment of all the genomic information rather than of common markers such as only $16 \mathrm{~S}$ rRNA. Next-generation sequencing of the genomes of all microorganisms in the sample instead of a specific marker location also serves as bioinformatic data to be mined in future studies.

\section{Materials and methods}

\subsection{Cave description and sample collection}

Çal Cave is located within Çal countyside at an altitude of $1154 \mathrm{~m}, 5 \mathrm{~km}$ southwest of Düzköy town, Trabzon, Turkey ( $40^{\circ} 51^{\prime} 55.1592^{\prime \prime} \mathrm{N}$ and $\left.39^{\circ} 22^{\prime} 45.4368 " \mathrm{E}\right)$. The entrance of the cave is about human height. Inside the cave the height reaches $25-30 \mathrm{~m}$ in some sections. The cave, which is estimated to have a length of approximately $4 \mathrm{~km}$. It is also considered among the longest caves in Turkey. Çal Cave has an underground water channel with a small stream flowing through it. The average temperature of Çal Cave varies between $12-15{ }^{\circ} \mathrm{C}$. It is one of the caves with high humidity due to having underground water (Zaman et al., 2011). For this study, cave soil samples were taken from the cave floor in aseptic condition using sterile $50 \mathrm{ml}$ Falcon tubes. The soil samples were obtained from approximetely 100-200 m away from the cave entrance and from 0-5 cm depth from the ground, from the dark zone and right down the cave wall. Additionally, the location was chosen as a place where is prevented from human contact. The samples were only handled with sterile stainless steel spoons and not touched by ungloved hands. Samples were stored at $4{ }^{\circ} \mathrm{C}$ prior to DNA extraction.

\subsection{DNA extraction for metagenomic analysis}

Metagenomic DNA from the cave soil samples was extracted according to a modified SDS-based method by Zhou et al. (2007). A $5 \mathrm{~g}$ soil sample was mixed with 13.5 $\mathrm{ml}$ of DNA extraction buffer $(100 \mathrm{mM}$ Tris- $\mathrm{HCl}[\mathrm{pH} 8.0]$, $100 \mathrm{mM}$ sodium EDTA [pH8.0], $100 \mathrm{mM}$ sodium phosphate [pH 8.0], 1.5 M NaCl, 1\% CTAB) and $100 \mathrm{ml}$ of proteinase $\mathrm{K}(10 \mathrm{mg} / \mathrm{ml})$ in sterile $50 \mathrm{ml}$ Falcon tubes by horizontal shaking at $225 \mathrm{rpm}$ for $30 \mathrm{~min}$ at $37^{\circ} \mathrm{C}$. Following shaking, $1.5 \mathrm{ml}$ of $20 \%$ SDS was added, and the sample was incubated in a $65^{\circ} \mathrm{C}$ incubator for $2 \mathrm{~h}$ with gentle end-over-end inversions every 15 to $20 \mathrm{~min}$. The supernatant was collected after centrifugation at $6.000 \mathrm{x} \mathrm{g}$ for $10 \mathrm{~min}$ at room temperature and transferred into $50 \mathrm{ml}$ centrifuge tubes. The soil pellets were extracted two more times by adding $4.5 \mathrm{ml}$ of the extraction buffer and $0.5 \mathrm{ml}$ of $20 \%$ SDS, as before. Supernatants from the three cycles of extractions were combined and mixed with an equal volume of chloroform: isoamyl alcohol (24:1, vol/vol). The aqueous phase was recovered by centrifugation and precipitated with 0.6 volume of isopropanol at room temperature for $1 \mathrm{~h}$. The pellet of crude nucleic acids was obtained by centrifugation at $16.000 \mathrm{x} \mathrm{g}$ for $20 \mathrm{~min}$ at room temperature, washed with cold $70 \%$ ethanol, and re-suspended in sterile deionised water, to give a final volume of $50 \mu \mathrm{l}$. The integrity of $5 \mu \mathrm{l}$ total DNA was analysed on $1 \%$ agarose with SYBR ${ }^{\circledR}$ safe DNA gel stain. The 260/280 ratio of extracted metagenomic DNA was measured using the NanoDrop ${ }^{\circledR}$ ND-1000 Spectrophotometer (ThermoFisher Scientific Inc., Milan, Italy). 


\subsection{DNA sequence analysis}

Total DNA concentration was adjusted to $200 \mathrm{ng}^{-1} \mathrm{l}^{-1}$ and sequence analysis of the sample was performed by using Illumina HiSeq $(2 \times 150 \mathrm{bp})$ chemistry in GATC Biotech AG, Germany (INVIEW Metagenome Explore). Paired-end Illumina reads were merged using the tool PEAR 0.9.6 Paired-End reAd mergeR (Zhang et al., 2014). Low-quality calls were removed before proceeding with further bioinformatic processing. Using a sliding window approach, bases with low quality were removed from the 3' and 5' ends. Bases were removed if the average Phred quality was below 15. Finally, only mate pairs (forward and reverse read) were used for the next analysis step after removing host sequence reads. The most abundant sequences in each Operational Taxonomic Unit (OTU) were selected as representative sequences and used for the taxonomic assignment using the BLAST algorithm (Altschul et al., 1990)

\section{Results and discussion}

\subsection{Taxonomic profiling}

The total number of high-quality reads of our sample was 29.355.096 (99.0\%) (Table 1). After screening and removing host sequence reads, non-host reads were subjected to a taxonomic profiling algorithm. Taxonomic profiling was done using Kraken (Wood and Salzberg, 2014) and the MiniKraken reference database. As a result, $8.398 \%$ (2.462.1269) of total reads (29.355.096) were classified into a specific kingdom and $91.6 \%$ (26.892.970) of total reads were unclassified. Taxonomic profiling results produced by Kraken were used to generate interactive plots using Krona (Ondov et al., 2011) for intuitive exploration of the relative abundances and confidences within the complex hierarchies of metagenomic classifications.

Taxonomic analysis revealed that the Çal Cave soil sample contained 98\% Bacteria, 2\% Eukaryota, 0.3\% Archaea, and $0.01 \%$ Virus. Figure 1 shows the taxonomic distribution of microbial diversity detected from all domains.

$\underline{\text { Table } 1 . \text { Sequence quality metrics of Çal Cave soil sample }}$

\begin{tabular}{lclll}
\hline Sample & Total reads & $\begin{array}{c}\text { Low quality } \\
\text { reads }\end{array}$ & $\begin{array}{c}\text { Single } \\
\text { reads }\end{array}$ & $\begin{array}{c}\text { High quality } \\
\text { reads }\end{array}$ \\
\hline Çal & 29.657 .720 & $\begin{array}{l}169.166 \\
(0.6 \%)\end{array}$ & $\begin{array}{l}133.458 \\
(0.4 \%)\end{array}$ & $\begin{array}{l}29.355 .096 \\
(99.0 \%)\end{array}$ \\
Cave & & $(0.6 \%)$ &
\end{tabular}

(b)

Phylum level distribution

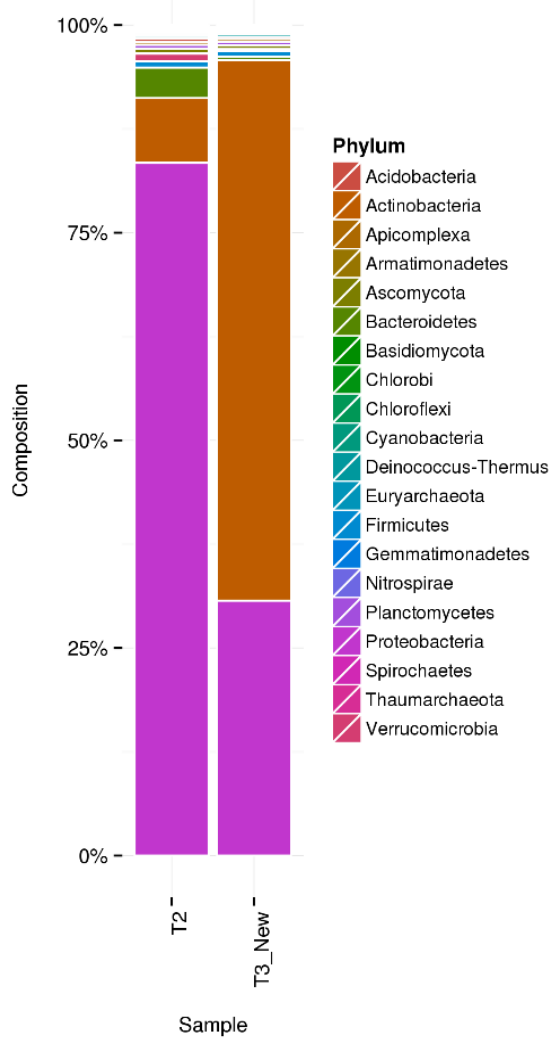

Figure 1. Bar plots showing the taxonomic abundance across the samples. a) Taxa-level: Genus; the most abundant genus is Streptomyces. b) Taxa-level: Phylum; the most abundant phylum is Actinobacteria 


\subsection{Diversity of bacteria}

Metagenomic profiling revealed that 31 distinct bacterial phyla were represented in the Çal Cave soil sample. Among them, the two phyla Actinobacteria (65\%) and Proteobacteria (31\%) were dominantly represented. Firmicutes (0.9\%), Planctomycetes (0.6\%) and Acidobacteria $(0.4 \%)$ which are the phylum often found in cave ecosystems (Oliveira et al., 2017) were poorly represented in Çal Cave.

Actinobacteria, which is the predominant phylum in our sample, can be found in relatively large percentages of cave habitats (De Mandal et al., 2017; D’Auria et al., 2018). In Actinobacteria, the most prevalent classes were detected as Pseudonocardiaceae (26\%), Propionibacteriales (17\%), Corynebacteriales (14\%), Streptomycetaceae (14\%), Micrococcales (9\%), Mycobacterium (6\%) and Micromonosporaceae (5\%). Among them, the most dominant genera were Streptomyces (12\%) (Figure 2) and Kribbella flavida (10\%). Actinobacteria and the genus Streptomyces are well known as potential sources of bioactive compounds, including antibiotics, antimetabolites and antitumor agents (Ghosh et al., 2017). Yücel and Yamaç (2010) isolated the Streptomyces species from soil samples of 19 different karstic caves in Turkey and they recorded the antimicrobial activity of the extracted compounds by using classical culturing techniques. Differently, by using the metagenomic approach, in this paper, we report crucial information about the gene sources of not only the culturable, but also un-culturable Actinobacteria species in Çal Cave.

Proteobacteria, the other major phylum in the investigated population, was represented in up to $31 \%$ of all reads in the Çal Cave soil sample. Proteobacteria are commonly found in caves and are known through the formation of ferromanganese deposits (Wiseschart et al., 2018). This phylum was divided into 4 classes in our sample: Alphaproteobacteria (50\%), Gammaproteobacteria (23\%), Betaproteobacteria (17\%) and Deltaproteobacteria (10\%). In Alphaproteobacteria, the most abundant genera were Rhizobiales and Sphingomonadales which were represented as $41 \%$ and $40 \%$, respectively. Caulobacteraceae (6\%), Rhodospirillales (6\%) and Rhodobacteriales (5\%) were detected below 10\%. In Gammaproteobacteria, the most read taxa were Xanthomonadales (51\%), Pseudomonadales (21\%), Chromatiales (12\%) and Enterobacteriaceae (6\%). As for Betaproteobacteria class, the most abundant order was Burkholderiales $(77 \%)$. The most representative order was Myxococcales (76\%) in Deltaproteobacteria.

In the bacterial population, Rhodococcus fascians, which is reported to have a role in the calcite biomineralisation process (Rusznyák et al., 2011), was found in high ratios. Besides, we detected some important antibiotic producing species which are Kutzneria albida (1.5\%), Saccharopolyspora erytraea (1.4\%), Saccharothrix espanaensis (1.2\%), and Amycolatopsis mediterranei $(1.5 \%)$. There were a number of chemoautotrophs such as those involved in manganese oxidation, e.g., Geobacter, ammonium oxidation, Bacillus and Nitrospira, sulfur oxidation, and Paracoccus and Thiobacillus. These bacteria are linked with the formation of speleothems.

\subsection{Diversity of eukaryota}

Taxonomic analysis revealed that Fungi (44\%) and Apicomplexa (30\%) were the two most abundant groups of Eukaryota. Data analysis showed that Ascomycota (80\%) was the most abundant phylum in the Fungi. Studies about the mycofloral diversity of cave environments are fewer than those focusing on bacterial diversity and those studies have reported that Ascomycota is the most abundant phylum in cave samples (Ghosh et al., 2017). The remaining fungi diversity was classified as Basidiomycota (19\%), Microsporidia (0.4\%) and Chytridiomycetes $(0.1 \%)$.

The readings corresponding to the Ascomycota phylum were represented as 5 classes of fungi: Sordariomycetes (44\%), Eurotiomycetes (22\%), Dothideomycetes (14\%), Leotiomycetes $(12 \%)$, and Saccharomycetales $(7 \%)$. The largest class Sordariomycetes, which spreads in terrestrial and aquatic environments, could be the pathogens of plants, arthropods and mammals. Several studies prove that fungi from Sordariomycetes have industrially important gene sources. Ramakrishnan et al., (2018) recently reported two types of III polyketide synthases from microorganisms belonging to Sordariomycetes (Sordaria macrospora and Chaetomium thermophilum) and showed that these enzymes have high catalytic efficiency for the synthesis of novel polyketide scaffolds with promising biological activity. The other considerable fungi class is Eurotiales known as a secondary metabolite producer. Especially, Aspergillus nidulans and Aspergillus terreus have been predicted to have approximately 50-70 biosynthetic gene clusters for polyketide synthases (PKS), non-ribosomal peptide synthases (NRPS), terpene cyclases and prenyl transferases (Inglis et al., 2013).

The second most common Eukaryota class in the sample, Apicomplexa (30\%), are known as parasites of all marine and terrestrial vertebrates including humans. Among them, the most abundant species was Hammondia hammondi (78\% of Apicomplexa). They have significant research potential because it is considered that only $0.1 \%$ of the 1-10 million Apicomplexan species have been described to date (Morin-Adeline at al., 2011).

\subsection{Diversity of archaea}

94\% of the Archaea, which accounts for $0.3 \%$ of total microbial diversity in the sample, were classified as Euryarchaeota. In the Euryarchaeota phylum, Halobacteria and Methanomicrobia genera were represented as $77 \%$ and $16 \%$, respectively.

Halobacteria, which is an extremely halophilic archaea, produces biologically active compounds in response to environmental changes (UV radiation, temperature anomalies, oxidative stress, lack of nutrients, oxygen availability or dehydration) and to interaction with other microorganisms. These biologically active compounds are of widespread interest in several biotechnology industries (Kalenov et al., 2018). Sorokin et al., (2018) reported that strains from extremely halophilic Euryarchaea use insoluble celluloses, cellobiose, as their carbon and energy source. 


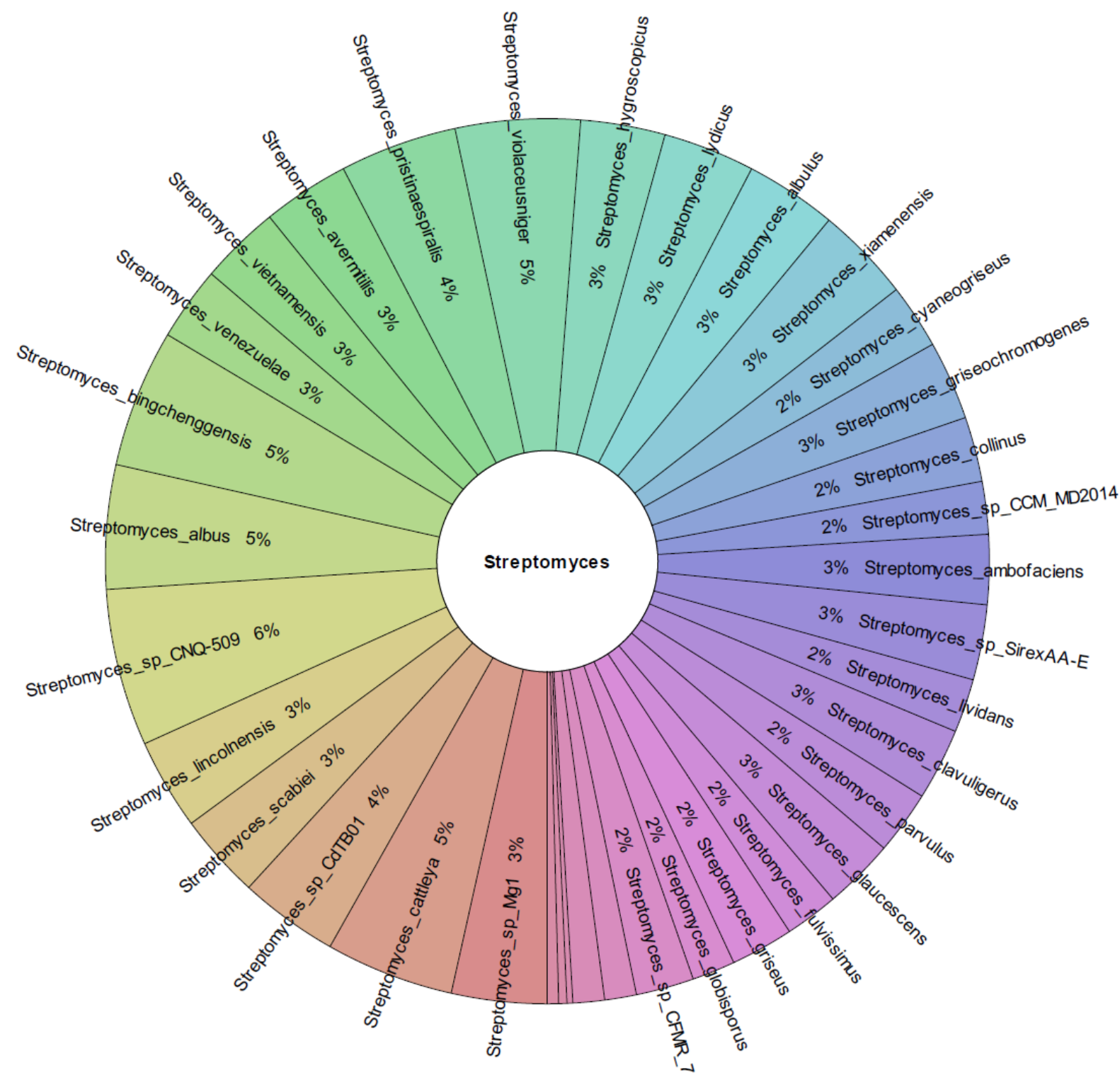

Figure 2. Species diversity of Streptomyces: 36 species were defined belonging to Streptomyces, which is the predominant genus in the Çal Cave soil sample. The plot was produced by using Krona (Ondov et al., 2011)

\subsection{Diversity of viruses}

The most abundant class of viruses dwelling in Çal Cave was determined as Caudovirales (40\%) which are tailed bacterial viruses infecting bacteria and archaea (King et al., 2011). Herpesvirales was represented in up to $13 \%$ of all the viruses. It was established that all of the order Herpesvirales belong to the family Herpesviridae which contains the mammal, bird and reptile viruses (Davison et al., 2009). The other two groups of viruses were Phycodnaviridae (13\%) that infects algae, and Invertebrate Iridovirus (13\%) that has probably been transmitted by endoparasitic wasps or parasitic nematodes (King et al., 2011). The other taxa represented below $10 \%$ were Baculoviridae (3\%) and Inovirus (3\%). Rhodobacter Phage and Human endogenous retrovirus accounted for $4 \%$ of readings.

\section{Conclusion}

Each cave has a unique biological habitat and consequently microbial diversity which is affected by its own physical or chemical properties. Therefore, every cave offers its source for industrially relevant molecules. This study represents detailed identification of the microbial diversity of Çal Cave including microorganisms from all hierarchies for the first time in virtue of the whole genome sequencing metagenomic approach. Classified reads showed that cave soil was dominated by Actinobacteria and Proteobacteria. Eukaryota, Archaea and Viruses were poorly represented in the cave habitat. Without distinguishing the origin, the most seen genera in the cave soil samples were Streptomyces, Kribbella, Mycobacterium and Amycolatopsis, detected as $8 \%, 6 \%, 4 \%$ and $4 \%$, respectively of the whole microbial population. Beside the classified diversity, $91.61 \%$ of the total reads which could not be classified according to any specific kingdom, verify 
that there exists vast microbial biodiversity in Çal Cave, and as these could not be identified with classical microbiology techniques, this habitat provides a promising source for novel enzymes and bioactive compounds. Our future research will build on the characterisation of these potential genes to correlate with their biological activity.

\section{Acknowledgements}

This work was supported by the Research Fund of Y1ldiz Technical University, Project Number: FDK-2019-3586.

\section{References}

Altschul, S.F., Gish, W., Miller, W., Myers, E.W., Lipman, D.J., 1990. Basic local alignment search tool. Journal of Molecular Biology, 215(3): 403-410.

Cheeptham, N., 2012. Cave Microbiomes: A Novel Resource for Drug Discovery. 1st ed. Springer Science \& Business Media. New York, NY, USA.

Davison A.J., Eberle R., Ehlers, B., Hayward, G.S., McGeoch, D.J., Minson, A.J., Pellett, P.E., Roizman, B., Kovler, M.B., Studdert, M.J., 2009. The Order Herpesvirales. Archives of Virology, 154(1): 171-177.

D’Auria, G., Artacho, A., Rojas, R.A., Bautista, J.S., Méndez, R., Gamboa, M.T., Gómez-Cruz, R., 2018. Metagenomics of Bacterial Diversity in Villa Luz Caves with Sulfur Water Springs. Genes, 9(1): 55-68.

De Mandal, S., Chatterjee, R., Kumar, N.S., 2017. Dominant bacterial phyla in caves and their predicted functional roles in $\mathrm{C}$ and $\mathrm{N}$ cycle. BMC Microbiology, 17(1): 90-99.

Ghosh, S., Kuisiene, N., Cheeptham, N., 2017. The cave microbiome as a source for drug discovery: Reality or pipe dream? Biochemical Pharmacology, 134:18-34.

Grothet, I., Vettermann, R., Schuetze, B., Schumann, P., SáizJiménez, C., 1999. Actinomycetes in karstic caves of northern Spain (Altamira and Tito Bustillo). Journal of Microbiological Methods, 36 (1-2): 115-122.

Inglis, D.O., Binkley, J., Skrzypek, M.S., Arnaud, M.B., Cerqueira, G.C., Shah, P., Sherlock, G., 2013. Comprehensive annotation of secondary metabolite biosynthetic genes and gene clusters of Aspergillus nidulans, A. fumigatus, $A$. niger and $A$. oryzae. BMC Microbiology, 13(1): 91-114.

Jones, D.S., Schaperdoth, I., Macalady, J.L., 2016. Biogeography of sulfur-oxidizing Acidithiobacillus populations in extremely acidic cave biofilms. The ISME Journal, 10(12): 2879-2891.

Kalenov, S.V., Gordienko, M.G., Murzina, E.D., Poberezhniy, D.Y., Baurin, D.V., Suzina, N.E., Yarovaya, O.V., 2018. Halobacterium salinarum storage and rehydration after spray drying and optimization of the processes for preservation of carotenoids. Extremophiles, 22(3): 511-523.

Katz, M., Hover, B.M., Brady, S.F., 2016. Culture-independent discovery of natural products from soil metagenomes. Journal of Industrial Microbiology \& Biotechnology, 43(2-3): 129-141.

King, A.M., Lefkowitz, E., Adams, M.J., Carstens, E.B., 2011. Virus taxonomy: Ninth report of the International Committee on Taxonomy of Viruses. 1st ed. Elsevier, San Diego, CA, USA.

Mendoza, M.L.Z., Lundberg, J., Ivarsson, M., Campos, P., Nylander, J.A.A., Sallstedt, T., Dalen, L., 2016. Metagenomic analysis from the interior of a speleothem in Tjuv-Ante's Cave, Northern Sweden. PLoS One, 11(3): e0151577.
Morin-Adeline, V., Vogelnest, L., Dhand, N.K., Shiels, M., Angus, W., Šlapeta, J., 2011. Afternoon shedding of a new species of Isospora (Apicomplexa) in the endangered Regent Honeyeater (Xanthomyza phrygia). Parasitology, 138(6):713-724.

Oliveira, C., Gunderman. L., Coles, C.A., Lochmann, J., Parks, M., Ballard, E., Thomas, D.J., 2017. 16S rRNA Gene-Based Metagenomic Analysis of Ozark Cave Bacteria. Diversity, 9(3): 31-47.

Ondov, B.D., Bergman, N.H., Phillippy, A.M., 2011. Interactive metagenomic visualization in a web browser. BMC Bioinformatics, 12(1): 385-394.

Ramakrishnan, D., Tiwari, M.K., Manoharan, G., Sairam, T., Thangamani, R., Lee, J.K., Marimuthu, J., 2018. Molecular characterization of two alkylresorcylic acid synthases from Sordariomycetes fungi. Enzyme and Microbial Technology, 115:16-22.

Rastogi, G., Sani, R.K., 2011. Molecular techniques to assess microbial community structure, function, and dynamics in the environment. In Microbes and Microbial Technology, Springer, New York, NY, pp. 29-57.

Riquelme, C., Dapkevicius, M.D.L.E., Miller, A.Z., CharlopPowers, Z., Brady, S., Mason, C., Cheeptham, N., 2017. Biotechnological potential of Actinobacteria from Canadian and Azorean volcanic caves. Applied Microbiology and Biotechnology, 101(2): 843-857.

Rusznyák, A., Akob, D.M., Nietzsche, S., Eusterhues, K., Totsche, K.U., Neu, T.R., Katzschmann, L., 2011. Calcite biomineralization by bacterial isolates from the recently discovered pristine karstic Herrenberg cave. Applied and Environmental Microbiology, 78(4): 1157-1167.

Schabereiter-Gurtner, C., Lubitz, W., Rölleke, S., 2003. Application of broad-range 16S rRNA PCR amplification and DGGE fingerprinting for detection of tick-infecting bacteria. Journal of Microbiological Methods, 52(2): 251-260.

Sorokin, D.Y., Khijniak, T.V., Kostrikina, N.A., Elcheninov, A.G., Toshchakov, S.V., Bale, N.J., Kublanov, I.V., 2018. Natronobiforma cellulositropha gen. nov., sp. nov., a novel haloalkaliphilic member of the family Natrialbaceae (class Halobacteria) from hypersaline alkaline lakes. Systematic and Applied Microbiology, 41(4): 355-362.

Wiseschart, A., Mhuanthong, W., Thongkam, P., Tangphatsornruang, S., Chantasingh, D., Pootanakit, K., 2018. Bacterial Diversity and Phylogenetic Analysis of Type II Polyketide Synthase Gene from Manao-Pee Cave, Thailand. Geomicrobiology Journal, 35(6): 518-527.

Wood, D.E., Salzberg, S.L., 2014. Kraken: ultrafast metagenomic sequence classification using exact alignments. Genome Biology, 15(3): R46.

Yücel, S., Yamaç, M., 2010. Selection of Streptomyces isolates from Turkish karstic caves against antibiotic resistant microorganisms. Pakistan Journal of Pharmaceutical Science, 23 (1): 1-6.

Zaman, M., Şahin, İ.F., Birinci, S., 2011. The Importance of Çal Cave (Düzköy-Trabzon) and its Surroundings as Regards Ecotourism Potential. Doğu Coğrafya Dergisi, 16(26): 24-47.

Zhang, J., Kobert, K., Flouri, T., Stamatakis, A., 2014. PEAR: A fast and accurate Illumina Paired-End reAd mergeR. Bioinformatics, 30(5): 614-620.

Zhou, J., Gu, Y., Zou, C., Mo, M., 2007. Phylogenetic diversity of bacteria in an earth-cave in Guizhou Province, Southwest of China. The Journal of Microbiology, 45(2): 105-112. 